\title{
KANDUNGAN KAROTEN KERUPUK SIMULASI WORTEL (Daucus carota L.) VARIASI SUHU PENYIMPANAN
}

\author{
[The Carotene Content from Carrot Simulation Crackers with Varied Time Storage] \\ Ulfa Mustika Sari $^{{ }^{*}}$, Syaiful Bahri ${ }^{1}$, Dwi Juli Puspitasari ${ }^{1}$ \\ 1 Jurusan Kimia Fakultas MIPA, Universitas Tadulako \\ Jl. Soekarno Hatta Km.9, Kampus Bumi Tadulako Tondo Palu, Telp. 0451- 422611 \\ *)Coresponding author: ulfaa1994@gmail.com(082259058086)
}

Diterima 10 Januari 2018, Disetujui 15 Februari 2018

\begin{abstract}
The research about the content of carotene from carrot simulation crackers with varied time storage has been performed. The aim is to find out the shelf life of processed products crackers carrots stored at room temperature based on the content of carotene from crackers. The research covered the stages of production and storage time crackers at room temperature. Stages of production were carried out by simulation method of crackers. Crackers carrots were stored at room temperature for 63 days with an observation interval of retention of carotene every 7 days. The results showed the initial content of carotene was $75.80 \mathrm{mg} / 100 \mathrm{~g}$ and content of carotene crackers from first to ninth week (or 63 days) were $71 \mathrm{mg} / 100 \mathrm{~g}, 68.5 \mathrm{mg} / 100 \mathrm{~g}, 62 \mathrm{mg} / 100 \mathrm{~g}, 59.5 \mathrm{mg} / 100 \mathrm{~g}, 55 \mathrm{mg} / 100 \mathrm{~g}, 52.5 \mathrm{mg} / 100 \mathrm{~g}$, $49 \mathrm{mg} / 100 \mathrm{~g}, 45 \mathrm{mg} / 100 \mathrm{~g}, 43.5 \mathrm{mg} / 100 \mathrm{~g}$ and $40 \mathrm{mg} / 100 \mathrm{~g}$, respectively. Shelf life of crackers based on order reaction one was 133 days with carotene content of $21.3 \mathrm{mg} / 100 \mathrm{~g}$.
\end{abstract}

Keywords: carrots, carotene, crackers simulated carrots, shelf time

\begin{abstract}
ABSTRAK
Telah dilakukan penelitian mengenai kandungan karoten kerupuk simulasi wortel variasi waktu penyimpanan.Tujuannya adalah untuk mengetahui umur simpan kerupuk produk hasil olahan wortel pada penyimpanan suhu ruang berdasarkan kandungan karoten dari kerupuk tersebut. Penelitian meliputi tahap produksi kerupuk dan waktu penyimpanan kerupuk pada suhu ruang. Tahap produksi kerupuk dilakukan dengan metode simulasi. Kerupuk wortel disimpan pada suhu ruang selama 63 hari dengan selang waktu pengamatan retensi karoten setiap 7 hari. Hasil penelitian menunjukkan kandungan karoten awal $75,80 \mathrm{mg} / 100 \mathrm{~g}$ dan kandungan karoten kerupuk minggu pertama hingga minggu 9 (atau 63 hari) secara berturut-turut $71 \mathrm{mg} / 100 \mathrm{~g}, 68,5 \mathrm{mg} / 100 \mathrm{~g}, 62 \mathrm{mg} / 100 \mathrm{~g}, 59,5 \mathrm{mg} / 100 \mathrm{~g}$, $55 \mathrm{mg} / 100 \mathrm{~g}, 52,5 \mathrm{mg} / 100 \mathrm{~g}, 49 \mathrm{mg} / 100 \mathrm{~g}, 45 \mathrm{mg} / 100 \mathrm{~g}, 43,5 \mathrm{mg} / 100 \mathrm{~g}$ dan $40 \mathrm{mg} / 100 \mathrm{~g}$. Masa simpan kerupuk berdasarkan reaksi orde satu adalah 133 hari dengan kandungan karoten $21,3 \mathrm{mg} / 100 \mathrm{~g}$.
\end{abstract}

Kata kunci: wortel, karoten, kerupuk simulasi wortel, masa simpan 


\section{LATAR BELAKANG}

Wortel termasuk jenis sayuran yang sangat popular di Indonesia mengandung zat-zat yang bermanfaat bagi kesehatan manusia, diantaranya provitamin $\mathrm{A}$, vitamin C, vitamin B, dan zat-zat lainnya (Kumalaningsih, 2006). Produksi wortel telah menjadi salah satu mata dagang komoditas pertanian antar negara-negara. Produksi wortel di sulawesi tengah menurut Badan Pusat Statistik (2013), $108,03 \mathrm{Kw} / \mathrm{Ha}$. Adapun luas wilayah panennya pada tahun $201335 \mathrm{Ha}$.

Jumlah panen wortel sangat melimpah sedangkan daya serap masyarakat tidak terlalu tinggi sehingga produksi dari petani banyak yang rusak. Sementara itu kandungan provitamin A yang tinggi sangat potensial untuk dimanfaatkan, oleh karenanya diperlukan penanganan lebih lanjut menjadi bentuk diversifikasi produk wortel. Pemanfaatan wortel tersebut dapat dilakukan dengan penambahan tepung terigu atau sumber pati lainnya untuk menjadi pangan fungsional yang selanjutnya dapat bertahan lama. Salah satu produk olahan wortel tersebut ialah kerupuk simulasi dengan kadar air yang rendah sehingga tahan lama dan mengandung beta karoten sebagai antioksidan (Sinaga, 2011).

Karoten secara alami memberikan pigmen warna oranye pada berbagai tumbuhan termasuk buah-buahan dan sayuran. Senyawa karoten memiliki aktivitas antioksidan yang tinggi sehingga dapat menjadi perlindungan terhadap kanker. Sifat dari senyawa karoten, yaitu nonpolar, mudah mengalami isomerisasi dan oksidasi, sebagai kromofor, bersifat hidrofobik (Suwandi, 1991, Dutta et al., 2005).

Wahyuni (2011) telah melakukan penelitian umur simpan sari wortel dan didapatkan waktu simpan untuk sari wortel pada penyimpanan suhu ruang adalah 38 hari. Waktu simpan yang dimiliki sari wortel yang cepat mengalami kerusakan maka perlu dilakukan pengolahan untuk mengoptimumkan pemanfaatan wortel salah satu adalah mengolahnya menjadi kerupuk simulasi.

Kerupuk simulasi terbuat dari bahan baku tepung pati yang dibuat melalui pembuatan lembaran tipis adonan dan dicetak kemudian diakhiri dengan penggorengan (Matz, 1992). Proses pengolahan produk pangan ini akan lebih mudah jika dilakukan beberapa modifikasi proses, seperti bahan baku dimasak atau dikukus sampai masak kemudian digiling bersama bahan-bahan lainnya atau dengan kata lain tidak dibuat dalam bentuk tepung terlebih dahulu (Kusbiantoro, 2005). Selain dari kualitas produk, hal lain yang perlu diperhatikan pada produk kerupuk adalah usia guna atau umur simpan.

Umur simpan didefinisikan sebagai rentang waktu atau usia dari produk yang masih layak untuk dikonsumsi dimana produk masih kondisi yang memuaskan baik dari segi organoleptik dan tentunya nilai gizi (Arpah dan Syarief, 2000) atau 
dengan kata lain hingga produk berada pada suatu tingkatan degradasi mutu tertentu (Floros, 1993). Umur simpan ditentukan dengan persamaan regresi $Y=$ $a X+b$, dimana $Y$ adalah konsentrasi karoten ketika mencapai waktu simpan dan $X$ adalah waktu simpan. Dengan menggunakan asumsi waktu simpan karoten terjadi ketika mencapai kandungannya telah $30 \%$ atau $70 \%$ karoten telah mengalami kerusakan (Kenyamu et al., 2014). Menurut Reynaldi (2010), umur simpan kerupuk wortel pada suhu ruang (suhu $25^{\circ} \mathrm{C}$ ) adalah 76 hari.

Untuk menjamin bahwa kerupuk simulasi wortel masih layak untuk dikonsumsi dan belum mengalami kerusakan diperlukan informasi tentang umur simpan. Studi umur simpan sangat penting terutama untuk produk pangan baru. Berdasarkan uraian diatas, maka, perlu dilakukan pengkajian mengenai umur simpan kerupuk wortel.

\section{METODE PENELITIAN}

\section{Bahan dan Peralatan}

Bahan yang digunakan dalam penelitian ini adalah wortel, tepung tapioka, garam, heksan dan air.

Adapun alat-alat yang digunakan, meliputi pisau, neraca analitik, gelas ukur $50 \mathrm{~mL}$, gelas ukur $10 \mathrm{~mL}$, gelas ukur $25 \mathrm{~mL}$, pipet ukur $1 \mathrm{~mL}$, erlenmeyer $100 \mathrm{~mL}$, pipet tetes, corong kaca, shaker, kuvet, seperangkat alat spektronik uv-vis, kompor dan alat-alat yang umum digunakan dalam pembuatan kerupuk.

\section{Prosedur Penelitian}

Pembuatan Kerupuk Wortel (Mappiratu, 2012)

Mencampur $1000 \mathrm{~g}$ wortel yang telah direbus dan dihaluskan dengan $500 \mathrm{~g}$ tepung tapioka dan $15 \mathrm{~g}$ garam. Adonan dikukus selama kurang lebih 30 menit dan dipipihkan hingga tipis. Selanjutnya dikeringkan di bawah sinar matahari. Kerupuk yang sudah kering ditentukan kandungan karotennya menggunakan metode spektrofotometri.

\section{Analisis Karoten (Mappiratu, 1990)}

Analisis karoten dilakukan menggunakan metode spektrofotometri: sampel kerupuk sebanyak $2 \mathrm{~g}$ diekstrak dengan heksan sebanyak $20 \mathrm{~mL}$, kemudian dikocok pada agitasi $250 \mathrm{rpm}$ selama 1 jam. Ekstraksi dilakukan berulang hingga ekstraknya tidak berwarna. Ekstrak yang diperoleh diukur volumenya dan diukur absorbansinya pada panjang gelombang $444 \mathrm{~nm}$. Kadar karoten yang didapatkan dihitung menggunakan persamaan berikut:

$$
\mathrm{x}=\frac{\mathrm{AxY}}{\mathrm{E}_{1 \mathrm{~cm}}^{1 \%} \times 100}
$$

$$
\begin{array}{rll}
\text { Di mana: } & \mathrm{x} & =\text { Berat karoten }(\mathrm{g}) \\
\mathrm{A} & =\text { Absorbansi } \\
\mathrm{Y}= & \text { Jumlah volume ekstrak } \\
& \text { karoten }(\mathrm{mL}) \\
\mathrm{E}_{1 \mathrm{~cm}}^{19 \mathrm{~g}}= & \text { Koefisien ekstingsi molar } \\
& (2500)(\mathrm{mL} / \mathrm{g})
\end{array}
$$

$$
\text { Kadar karoten }=\frac{\text { Berat karoten }}{\text { Berat sampel }} \times 100 \%
$$




\section{Penentuan Masa Kadaluarsa}

Asumsi yang digunakan dalam penentuan masa kadaluarsa adalah kerusakan karoten yang mengikuti orde reaksi satu dan kerupuk dinyatakan kadaluarsa ketika karoten yang tersisa adalah $30 \%$ atau ketika tingkat kerusakan karoten mencapai $70 \%$. Pada tahap awal dibuat kurva hubungan antara In tingkat kerusakan atau In retensi karoten terhadap waktu, untuk mendapatkan persamaan regresi. Pada persamaan tersebut dimasukkan In 30\% untuk mendapatkan waktu kadaluarsa.

\section{HASIL DAN PEMBAHASAN}

\section{Produk Kerupuk Wortel}

Kerupuk simulasi dibuat melalui modifikasi proses berupa bahan baku wortel direbus terlebih guna mempermudah proses pencampuran adonan. Kadar karoten awal yang terdapat pada wortel yang telah dimasak adalah $75,80 \mathrm{mg} / 100 \mathrm{~g}$. Hasil yang didapatkan menunjukkan bahwa kandungan karoten pada wortel yang tidak ditepungkan lebih tinggi.

Menurut Rosida dan Purwanti (2008), kandungan tepung wortel yakni $63,67 \mu \mathrm{g} / 100 \mathrm{~g}$ lebih rendah dari kadar karoten yang didapatkan. Hal ini dapat terjadi dikarenakan proses penepungan membuat wortel mengalami kekurangan karoten yang mana karoten teroksidasi lama oleh matahari karena mengalami proses pengeringan berulang dan berkepanjangan.
Kerupuk yang telah dikeringkan pada sinar matahari selanjutnya dianalisis kadar karotennya dengan pelarut yang digunakan untuk melarutkan karoten adalah n-heksan. Hal ini dikarenakan nheksan merupakan pelarut non-polar sehingga cocok untuk melarutkan karoten, senyawa karoten cenderung larut sempurna apabila pelarut yang digunakan bersifat non-polar (Susilowati, 2008 dalam Fatima, 2013).

Pada perlakuan ini terbukti terdapat karoten pada hasil ekstrak kerupuk wortel dengan adanya warna kuning. Karotenoid adalah suatu pigmen yang berwarna kuning, orange atau merah orange. Selanjutnya dilakukan penentuan umur simpan produk.

\section{Masa Kadaluarsa Kerupuk Wortel}

Untuk mengetahui umur simpan suatu produk, ditentukan menggunkan persamaan regresi dari suatu hubungan antara mutu produk terhadap waktu simpan. mengingat orde reaksi perubahan mutu produk kerupuk simulasi wortel belum diketahui maka perlu dilakukan analisis orde reaksi yang akan digunakan melalui kurva perubahan mutu. Menurut Mappiratu (2012), bila usia simpan bahan pangan belum diketahui orde reaksinya, maka perlu ditentukan terlebih dahulu orde reaksinya melalui kurva hubungan antara parameter mutu A terhadap waktu (t) untuk orde nol dan In A terhadap waktu untuk orde satu. 
Penentuan orde reaksi didasarkan atas bentuk kurva, dimana untuk orde reaksi nol bentuk kurvanya adalah antara retensi terhadap waktu simpan. Untuk orde reaksi satu, bentuk kurvanya melalui hubungan antara In retensi terhadap waktu.

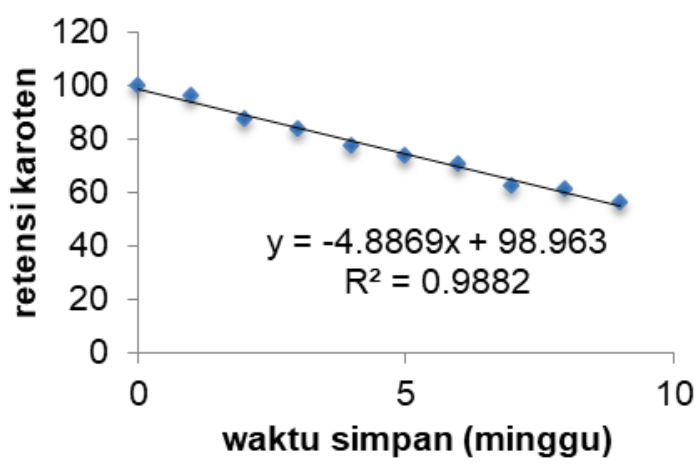

Gambar 1. Kurva hubungan retensi karoten terhadap waktu simpan untuk reaksi orde nol

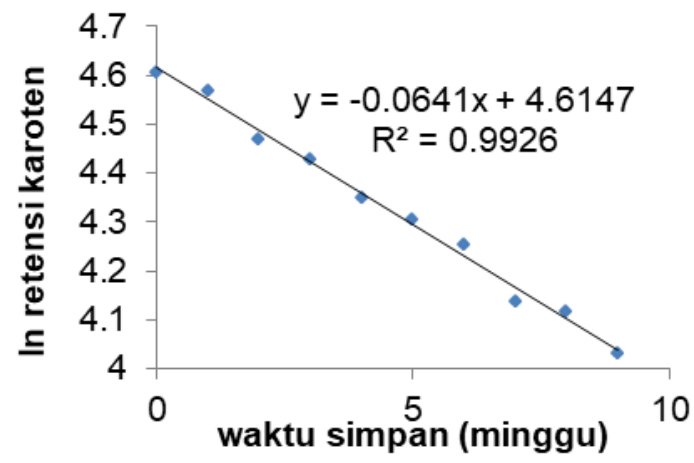

Gambar 2 Kurva hubungan In retensi karoten terhadap waktu simpan untuk reaksi orde satu

Hasil yang diperoleh menunjukkan $\mathrm{R}^{2}$ tertinggi terdapat pada kurva hubungan In retensi karoten terhadap waktu simpan (orde satu) yaitu 0,9926. Menurut Estiasih (2010) bahwa orde reaksi dengan nilai $R^{2}$ yang lebih besar merupakan orde reaksi yang digunakan. Dengan mengacu pada nilai $R^{2}$ maka penurunan mutu karoten mengikuti orde reaksi satu dengan persamaan regresi $\mathrm{y}=-0.0641 \mathrm{x}+4.6147$.

Mutu dari produk olahan akan mengalami perubahan selama masa penyimpanan, yang dimana pada saat tertentu mutunya tidak dapat lagi diterima. Jangka waktu yang menyebabkan mutu produk olahan pada saat penyimpanan tidak lagi dapat diterima disebut sebagai jangka waktu kadaluarsa atau umur simpan (shelf life) produk olahannya (Mappiratu, 2012). Parameter mutu umur simpan untuk kerupuk wortel adalah kandungan karoten yang terdapat didalamnya. Asumsi yang digunakan dalam penentuan masa kadaluarsa kerupuk wortel adalah retensi karoten telah mencapai $30 \%$ atau tingkat kerusakan karoten telah mencapai $70 \%$.

Tabel 1 Nilai retensi dan In retensi karoten pada kerupuk wortel selama penyimpanan pada suhu ruang

\begin{tabular}{cccc}
\hline No. & $\begin{array}{c}\text { Waktu } \\
\text { simpan } \\
\text { (hari) }\end{array}$ & $\begin{array}{c}\text { Retensi } \\
\text { karoten (\%) }\end{array}$ & $\begin{array}{c}\text { Ln retensi } \\
\text { karoten }\end{array}$ \\
\hline 1. & 0 & 100 & 4,6051 \\
2. & 7 & 96,4788 & 4,5693 \\
3. & 14 & 87,3239 & 4,4696 \\
4. & 21 & 83,8028 & 4,4284 \\
5. & 28 & 77,4647 & 4,3498 \\
6. & 35 & 73,9436 & 4,3033 \\
7. & 42 & 70,4225 & 4,2545 \\
8. & 49 & 62,6760 & 4,1379 \\
9. & 56 & 61,2676 & 4,1152 \\
10. & 63 & 56,3380 & 4,0313
\end{tabular}

Hasil pengukuran nilai dapat dilihat pada tabel 1, berdasarkan tabel dapat dilihat semakin lama penyimpanan kerupuk wortel semakin kecil kandungan 
karotennya. Menurut Mappiratu (2012), penurunan mutu akan berubah selama penyimpanan oleh adanya pengaruh lingkungan seperti suhu, kelembaban dan tekanan udara serta faktor komposisi pangan itu sendiri. Karoten adalah bentuk provitamin A yang paling aktif, memiliki sifat kimia yang mirip dengan vitamin $A$ yaitu sensitif terhadap oksigen, cahaya dan lingkungan asam. Mudah mengalami kerusakan disebabkan suatu suhu, cahaya, teknik pengeringan, penyimpanan, asam dan logam-logam berat. Data perubahan kandungan karoten kerupuk wortel tersebut diperoleh dengan cara menganalisis kandungan karoten menggunakan metode spektrofotometri .

Masa kadaluarsa atau waktu simpan karoten kerupuk wortel tercapai jika retensi karoten telah mencapai $30 \%$ atau In retensi karoten sebesar 3,401 . Sehingga diperoleh umur simpan kerupuk wortel adalah 133 hari dengan kandungan karoten $21,3 \mathrm{mg} / 100 \mathrm{~g}$.

Hasil yang diperoleh memiliki masa simpan yang lama dibandingkan dengan masa simpan sari wortel yang telah dilakukan oleh Wahyuni (2011) yang hanya bertahan pada 38 hari dan kerupuk wortel yang telah digoreng menurut Reynaldi (2010) memiliki masa simpan 76 hari. Sehingga untuk mengoptimalkan pemanfaatan wortel yang cepat mengalami kerusakan maka dibuat dalam bentuk kerupuk simulasi wortel siap goreng.

Kerupuk tanpa penambahan bahan pengawet maupun zat antioksidan memiliki umur simpan 107,9 hari (Puspita, 2016) Sementara berdasarkan hasil yang diperoleh kerupuk yang memiliki karoten memiliki masa simpan di atas 107,9 hari. Hal ini menunjukkan bahwa keberadaan senyawa antioksidan dalam kerupuk berperan memperpanjang masa simpan kerupuk. Hal tersebut kemungkinan disebabkan oleh fungsi karoten sebagai antioksidan yang mencegah proses oksidasi. Antioksidan bekerja menangkap radikal bebas dan melepaskan elektronnya sendiri, sehingga mencegah oksidasi oleh radikal bebas yang dapat merusak molekul-molekul lain.

\section{KESIMPULAN}

Berdasarkan hasil penelitian maka dapat disimpulkan bahwa masa simpan keripik wortel berdasarkan reaksi orde satu adalah 133 hari dengan kandungan karoten $21,3 \mathrm{mg} / 100 \mathrm{~g}$.

\section{DAFTAR PUSTAKA}

Arpah, M., Syarif, R. (2000). Evaluasi model-model Pendugaan Umur Simpan Pangan dari Difusi Hukum Fick Unidiereksional. Bul. Teknol dan industri pangan XI. 1-11

Badan Pusat Statistik. (2013). Produksi wortel. http://Bps.go.id diakses pada 3 Desember 2017.

Dutta, D., Chaudhuri, U. R., \& Chakraborty, R. (2005). Structure, health benefits, antioxidant property and processing and storage of carotenoids. African Journal of Biotechnology, 4(13).

Estiasih, T. (2010). Penentuan umur simpan jahe instan dengan metode accelarated shelf life test (ASLT) 
dengan pendekatan Arrhenius. Malang (ID): Universitas Brawijaya.

Fatimah, R. (2013). Penggunaan lempung sebagai adsorben karoten dalam metil ester asam lemak minyak sawit kasar. Skripsi. Palu: Universitas Tadulako.

Floros, J D. (1993). Shelf Life Prediction of Packaged Foods, Chemical, Biological, Physical and Nutrisional Aspects. London: Elsevier publ.

Kenyamu, M, Mappiratu, Nurakhirawati. (2014). Kajian Waktu Simpan Karoten Kapang Oncom Merah (Neurospora sp) yang Diproduksi pada Media Tongkol Jagung. Online Jurnal of Natural Science. 3(2): 6269.

Kumalaningsih, S. (2006). Antioksidan alami penangkal radikal bebas, sumber manfaat, cara penyediaan dan pengolahan. Surabaya: Trubusagrisana.

Kusbiantoro. (2005). Keripik singkong simulasi. Tekno pangan dan agro industry, vol:1 nomor 4. Teknologi pangan dan gizi. IPB.

Mappiratu. (1990). Produksi beta karoten pada limbah cair tapioca dengan kapang oncom merah. Tesis. Bogor: FBS- Institut Pertanian Bogor.

Mappiratu. (2012). Teknologi pangan. Palu: Tadulako University Press.

Matz SA. 1992. Snack Food Technology. 3rd ed. The AVI publ. Co. In. Westport. Connecticut.

Puspita, C. R., Rangga, A., \& Sartika, D. (2016). Kajian Lama Simpan Keripik Pisang Kepok Putih (Musa acuminate sp.) Berdasarkan Tingkat Aroma, Rasa dan Kerenyahan Organoleptik Dalam Berbagai Jenis Kemasan dengan Model Pendekatan Arrhenius. Inovasi Pembangunan: Jurnal Kelitbangan, 4(03), 278-292.

Reynaldi, R. (2010). Pendugaan Umur Simpan Keripik Wortel (Daucus
Carota L.) Dalam Kemasan Alumunium Foil dengan Metode Akselerasi. Skripsi. Bandung: ITB.

Rosida, Purwanti, I.I. (2008). Pengaruh Substitusi Tepung Wortel dan Lama penggorengan Vakum Terhadap Karakteristik Keripik Wortel Simulasi. Jurnal Teknologi Pertanian. 9(1): 19 24.

Sinaga, S. (2011). Pengaruh Subtitusi Tepung Terigu dan Jenis Penstabil dalam Pembuatan Cookies Labu Kuning. Skripsi. Medan: Universitas Sumatera Utara.

Susilowati. (2008). Pengukuran status gizi dengan antropametri gizi. Jakarta: Cv. Trans Info Media.

Suwandi, U. (1991). Manfaat Beta-karoten Bagi Kesehatan. Cermin Dunia Kedokteran. nomor 73. HIm 36-40.

Wahyuni, R. (2011). Penerapan Umur Simpan Sari Wortel Pada Biaya Penyimpanan Selama Pemasaran. AGROMIX, 3(5). 